\title{
Supercooling in Floral Buds of 'Danka' Black and 'Red Lake' Red Currants
}

\author{
Michele Warmund ${ }^{1}$ and Milon George ${ }^{2}$ \\ University of Missouri, Columbia, MO 65211' \\ Fumiomi Takeda ${ }^{3}$ \\ Appalachian Fruit Research Station, U.S. Department of Agriculture, Agricultural Research \\ Service, Keameysville, WV 25430
}

Additional index words. .,Ribes nigrum, Ribes sativum, cold hardiness, differential thermal analysis

\begin{abstract}
Differential thermal analyses (DTA) and freeze viability tests were conducted to investigate the biophysics of freezing in floral buds of 'Danka' black (Ribes nigrutn L.) and 'Red Lake' red currants [Ribe.s sativum (Rchb.) Syrne] sampled from Nov. 1989 through Mar. 1990. Scanning electron microscopy was also used to determine the relationship between floral morphology and the freezing characteristics of the buds. Floral buds had multiple abrupt low-temperature exotherms (LTEs) and one or two broad LTEs in DTA tests. Abrupt LTEs from DTA were associated with apparent injury to the inflorescence in viability tests. The number of LTEs did not correspond to the number of racemes or flowers per bud, indicating that several flowers froze simultaneously. DTA experiments conducted in Dec. 1990 revealed that the broad exotherm detected between - 14 and - 20C in 'Danka' samples resulted from freezing of supercooled water in the outer nonliving region of the periderm of cane tissue attached to the bud.
\end{abstract}

DTA has been used to study freezing in floral buds of several fruit genera. In DTA experiments, floral buds exhibit a nonlethal high-temperature exotherm (HTE), representing extracellular ice formation (Burke et al., 1976; Quamme, 1974). The HTE is followed by one or more LTEs associated with intracellular freezing of supercooled water in the floral prlmordia. In buds containing a racemose in florescente, such as Rubus, LTEs correspond to freezing injury of individual flowers (Warmund et al., 198\$) or to the entire floral region (Kraut et al., 1986; Warmund et al., 1990).

Previous research on Ribes spp. has focused on fall acclimation (Lobanov and Shcherbinin, 1990) or spring frost tolerance of R. nigrum after budbreak (Dale, 1981; Dale and Heiberg, 1984; Keep et al., 1983; Mather et al., 1980). The purpose of our study was to investigate supercooling in floral buds of 'Danka' black and 'Red Lake' red currants and to ascertain the relationship between floral morphology and freezing characteristics.

\section{Materials and Methods}

'Danka' black and 'Red Lake' red currant samples were collected from 21- and 6-year-old plants, respectively, growing at the Horticultural Research Station at Excelsior, Minn. One-yearold wood was obtained at 0.5 to $1 \mathrm{~m}$ above the soil surface on 13 Nov. 1989, 17 Jan. 1990, and 19 Mar. 1990 for DTA, viability tests, and scanning electron microscopy (SEM). On 10 Dec. 1990, 'Danka' samples were also obtained for DTA. All plant material was placed in sealed plastic bags containing moist paper towels, packed on ice, and shipped by overnight mail to the Univ. of Missouri where the freezing tests were conducted. Samples were stored at $2 \mathrm{C}$ for $24 \mathrm{~h}$ before being tested.

DTA. The DTA system used in this study has three sample chambers and a reference chamber, each containing a Yellow

Received for publication 11 Mar. 1991. Contribution from the Missouri Agricultural Experiment Station, Journal Series no. 11323. We thank D. Bedford and J. Luby for providing plant material. Technical assistance by Glen Davis is acknowledged. The cost of publishing this paper was defrayed in part by the payment of page charges. Under postal regulations, this paper therefore must be hereby marked advertisement solely to indicate this fact.

'Associate Professor, Dept. of Horticulture.

'Associate Professor, School of Natural Resources.

${ }^{3}$ Research Horticulturist.
Springs Instrument (Yellow Springs Instrument Co., Yellow Springs, Ohio) Series 400 thermistor probe connected to a signal conditioning network (George, 1982). The analog outputs from the signal conditioning network were converted to digital format and stored on floppy disks using an Analog Device AD363 data acquisition system (Analog Devices, Norwood, Mass. ) interfaced with a Southwest Technical Products (Southwest Technical Products Corp., San Antonio, Texas) 6809 microcomputer. Data were plotted on a Houston Instruments (Houston Instruments, Austin, Texas) $2000 \mathrm{X}-\mathrm{Y}$ plotter. The DTA system can resolve freezing events that produce differential temperatures of $\approx 0.001 \mathrm{C}$.

Intact buds were removed with a small section of adjacent stem tissue from the middle portion of 1-year-old canes for all dates, except 'Red Lake' buds tested on 19 Nov. On this date, bud scales and leaves surrounding the inflorescence were removed before being frozen. Each sample was placed in an aluminum foil cup and attached to a thermistor. An empty aluminum foil cup was attached to the reference sensor to balance the heat capacity of the reference and sample chambers. The temperature was lowered rapidly to $0 \mathrm{C}$ and cooling was initiated at $3 \mathrm{C} / \mathrm{h}$ when the bud temperature was within $2 \mathrm{C}$ of the reference temperature. Data were collected at $40-\mathrm{sec}$ intervals until the sample temperature reached $-40 \mathrm{C}$.

After the DTA test was completed, samples were removed from the chamber and placed in vials containing formalin-acetic acid-alcohol (FAA) fixative. Samples were mailed to the Appalachian Fruit Research Station, Kearneysville, W.Va., where they were dehydrated in a graded ethanol series, dissected, and examined under a stereoscope. Additional nonfrozen control samples were also fixed in FAA and prepared for SEM in Kearneysville. Dehydrated buds were critical-point-dried with $\mathrm{CO}_{2}$, sputter-coated with gold palladium alloy, and examined on a Cambridge StereoScan 120 electron microscope (Cambridge Instruments, Cambridge, England) operated at $8 \mathrm{kV}$.

In Dec. 1990, additional DTA experiments were conducted on the following tissues: 1) intact sections of canes in which the floral bud had been removed; 2) cane samples of pith and

Abbreviations: DTA, differential thermal analysis; HTE, high-temperature exotherm; LTE, low-temperature exotherm; SEM, scanning electron microscopy. 
xylem only; 3) phloem and periderm only; and 4) the nonliving portion of the periderm. In these experiments, the temperature in the freezer was lowered rapidly and cooling at 3 or $25 \mathrm{C} / \mathrm{h}$ was begun when the reference sensor reached 2 or $10 \mathrm{C}$, respectively. Data were collected at $40-\mathrm{sec}$ intervals when samples were cooled slowly and at 10 -sec intervals when cooled more rapidly.

Viability tests. Experiments with 'Danka' and 'Red Lake' were conducted on 15 Nov. 1989 and 19 Jan. and 21 Mar. 1990. Five samples $(3 \mathrm{~cm}$ each) were removed from canes as previously described, placed in moist cheesecloth, and wrapped in aluminum foil for each of the eight test temperatures. A 0.51 mm-diameter (24-gauge) copper constantan thermocouple was attached to the canes to monitor tissue temperature. Thermocouple output was recorded on a Honeywell (Honeywell Process Control Div., Fort Washington, Pa.) Electronic 112 multipoint recorder. Samples were placed in a programmable Tenney Jr. freezer (Tenney Engineering, Union, N.J.) and then held at - 3C for $12 \mathrm{~h}$. During this time, the cheesecloth froze and seeded the tissue with ice at about - 1C. After $12 \mathrm{~h}$, samples were cooled at $3 \mathrm{C} / \mathrm{h}$ and removed from the freezer at $3 \mathrm{C}$ intervals at temperatures estimated to result in bud injury. The tissue was then placed in thermos bottles at $2 \mathrm{C}$ and allowed to thaw for $24 \mathrm{~h}$. Samples were then incubated at room temperature for 5 days before examination of floral bud injury under a dissecting microscope.

\section{Results and Discussion}

DTA of bud samples. Two types of LTEs were detected from bud samples cooled at $3 \mathrm{C} / \mathrm{h}$ (Figs. 1 and 2). The first type of exotherm appeared as an abrupt deflection from the baseline. In flower buds of other genera, this type of LTE was correlated with the rapid release of heat following the crystallization of supercooled water in floral tissue (George et al., 1974; Quamme, 1974; Warmund et al., 1988). In 'Red Lake' samples, up to four abrupt LTEs were detected in November (Table 1). By January, one to 11 LTEs were evident in DTA plots, and in March, up to three abrupt exotherms were detected. At all three dates, both small $(\mathrm{s} 3 \mathrm{~mm})$ and large LTEs were present. The peak height of a LTE is related to the amount of water crystallizing after a nucleation event (Pope and Judd, 1977). The many LTEs detected in January may be related to bud moisture content. As tissues desiccate in winter, fractions of tissue water may become isolated. Nucleation of these small fractions of isolated water may have produced the numerous LTEs. Floral buds of 'Danka' also exhibited up to six sharp LTEs (Table 2). Both large and small exotherms were detected at all test dates. The median LTE for 'Red Lake' buds in November, January, and March was $-21.0,-18.1$, and -22 . IC, respectively. The median LTEs of 'Danka' at the same sampling dates were - 26.7, - 23.6, and - 26.5C, respectively. The median exotherm has been used by Andrews and Proebsting (1983) to estimate the $\mathrm{T}_{50}$ (temperature at which half the flowers were injured) of cherry buds.

The second type of exotherm detected in bud samples was a broad peak, indicating a prolonged freezing event (Figs. 1 and 2). In DTA thawing curves, this fraction of water melted above - 4C, indicating that this water also supercooled. In 'Red Lake' samples, one broad peak occurred in the range of -15 to $-22 \mathrm{C}$ at all test dates (Fig. 1). The average temperature at one-half the peak area $\left(\mathrm{TPA}_{50}\right)$ was $-19.9,-18.8$, and $-19.4 \mathrm{C}$ for November, January, and March, respectively (Tables 1 and 2). Two broad exotherms occurred in 'Danka' samples in the range
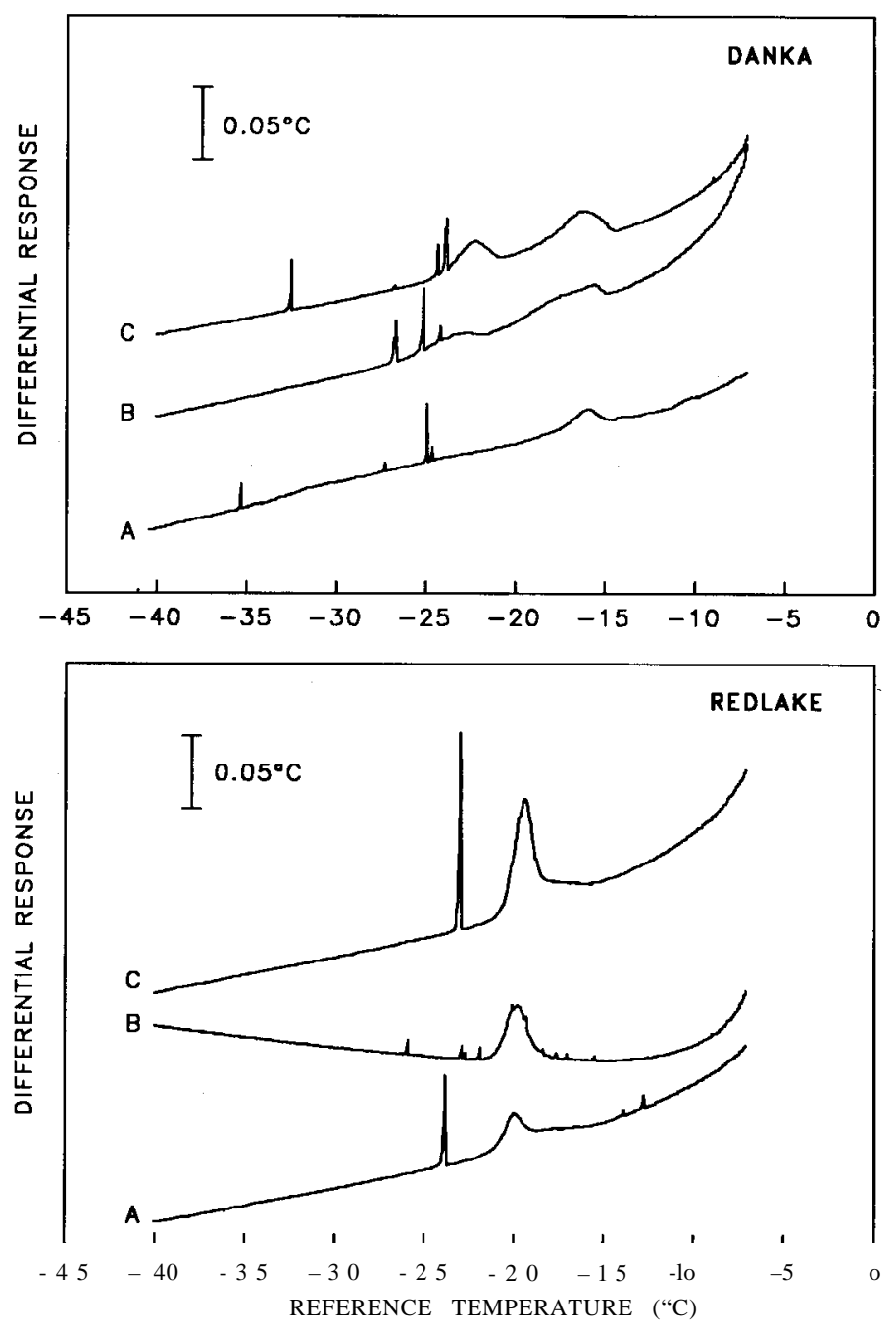

Fig. 1. DTA of 'Danka' black currant and 'Red Lake' red currant floral buds collected (A) 13 Nov. 1989, (B) 17 Jan. 1990, and (C) 19 Mar. 1990. HTEs not shown.

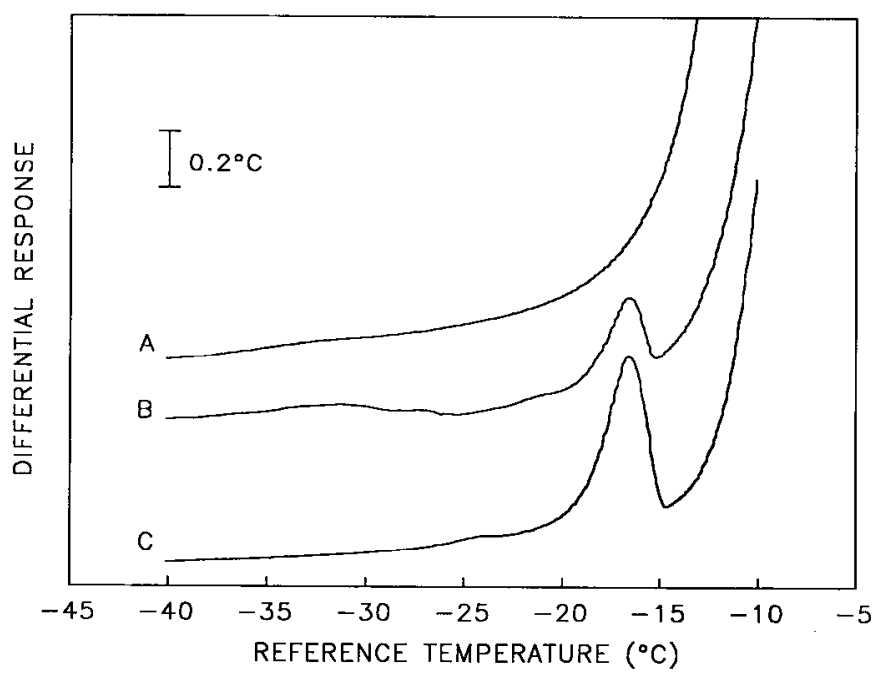

Fig. 2. DTA of 'Danka' canes sampled on 10 Dec. 1990 and cooled. at $25 \mathrm{C} / \mathrm{h}$. (A) Cane with phloem removed; (B) intact cane with floral bud removed; (C) nonliving periderm dissected from the cane. HTEs not shown. 
Table 1. LTEs of 'Red Lake' currant floral buds.

\begin{tabular}{|c|c|c|c|c|}
\hline \multirow{2}{*}{$\begin{array}{c}\text { Collection } \\
\text { date }\end{array}$} & \multirow{2}{*}{$\begin{array}{l}\text { DTA } \\
\text { test date }\end{array}$} & \multicolumn{3}{|c|}{ Temp of abrupt and broad LTEs $\left({ }^{\circ} \mathrm{C}\right)$} \\
\hline & & Bud 1 & Bud 2 & Bud 3 \\
\hline \multirow[t]{3}{*}{13 Nov. 1989} & 15 Nov. & $-29.6^{z}(-19.8)^{y}$ & $-12.4,-13.6$ & $-21.9(-20.1)$ \\
\hline & 16 Nov. & $\begin{array}{l}-7.2,-7.8,-16.8 \\
-17.2(-19.6)\end{array}$ & $-23.8(-20.0)$ & $-23.8(-20.1)$ \\
\hline & 19 Nov. & $\begin{array}{l}-7.6,-21.0 \\
-23.9(-19.6)\end{array}$ & $-25.2(-19.9)$ & $\begin{array}{l}-6.2,-13.6,-23.6, \\
-35.6(-20.0)\end{array}$ \\
\hline \multirow[t]{2}{*}{17 Jan. 1990} & 18 Jan. & $-21.0(-14.9,-20.3)$ & $\begin{array}{l}-5.6,-12.3,-13.2 \\
-16.2,-17.0,-18.2 \\
-18.5,-18.6,-18.8 \\
\quad-19.0,-22.4(-17.3,-19.9)\end{array}$ & $\ldots w$ \\
\hline & $20 \mathrm{Jan}$. & $\begin{array}{c}-15.2,-16.7,-17.3 \\
-18.0,-19.0,-19.8 \\
-21.6,-22.6,-22.8 \\
-25.7(-19.6)\end{array}$ & $\begin{array}{l}-7.6,-9.9,-10.2 \\
-12.7,-13.3,-13.7 \\
\quad-23.6(-19.5)\end{array}$ & $-23.4(-19.9)$ \\
\hline \multirow[t]{2}{*}{19 Mar. 1990} & 27 Mar. & ---w & $-20.0,-28.6(-19.3)$ & $\frac{-16.4,-17.0}{-20.0(-19.6)}$ \\
\hline & $\begin{array}{l}28 \text { Mar. } \\
29 \text { Mar. }\end{array}$ & $\begin{array}{l}-6.8,-12.6(-18.5) \\
-22.1(-19.1)\end{array}$ & $\begin{array}{l}-22.8(-19.4) \\
-22.6,=25.6(-19.2)\end{array}$ & $\begin{array}{l}-9.4, \frac{-25.1}{-22.0}, \frac{-23.0}{-23.3(-19.3)} \\
\end{array}$ \\
\hline
\end{tabular}

${ }^{2}$ Underlined exotherm temperatures indicate that the abrupt LTE peak height was $\leq 3 \mathrm{~mm}$.

$y$ Values in parentheses indicate the calculated temperature at one-half the area of the broad exotherms.

xBud scales and leaves were removed from the sample before freezing.

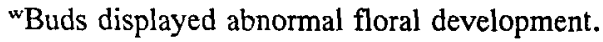

Table 2. LTEs of 'Danka' black currant floral buds.

\begin{tabular}{|c|c|c|c|c|}
\hline \multirow{2}{*}{$\begin{array}{l}\text { Collection } \\
\text { date }\end{array}$} & \multirow{2}{*}{$\begin{array}{c}\text { DTA } \\
\text { test date }\end{array}$} & \multicolumn{3}{|c|}{ Temp of abrupt and broad LTEs $\left({ }^{\circ} \mathrm{C}\right)$} \\
\hline & & Bud 1 & Bud 2 & Bud 3 \\
\hline 13 Nov. 1989 & $\begin{array}{l}17 \text { Nov. } \\
18 \text { Nov. }\end{array}$ & $\begin{array}{l}-18.4,-29.0(-16.1)^{\mathrm{z}} \\
-22.4,-22.6,-24.4, \\
-27.1, \frac{-27.8}{}(-16.2 \\
-23.3)\end{array}$ & $\begin{array}{l}-25.8,-29.4(-16.7) \\
-24.4,-24.7,-27.0 \\
-35.0(-16.1)\end{array}$ & $\begin{array}{l}-28.2^{y},-30.0(-16.6) \\
-10.2,-26.5,-26.9 \\
(-16.4,-23.2)\end{array}$ \\
\hline 17 Jan. 1990 & 19 Jan. & $\begin{array}{l}-15.3,-24.2,-25.7 \\
-27.1,-37.3(-16.7 \\
\quad-23.8)\end{array}$ & $\begin{array}{l}-16.0,-16.4,-18.1 \\
-23.6,(-16.8,-23.2)\end{array}$ & $\begin{array}{l}-23.9,-24.8,-26.4 \\
-26.6(-17.0,-23.4)\end{array}$ \\
\hline - & 21 Jan. & $\begin{array}{l}-8.0,-8.4,-20.0 \\
-20.1(-16.6,-23.5)\end{array}$ & $\begin{array}{l}\frac{-7.8}{-12.3},-8.0,-8.2 \\
\frac{(-16.9,-23.6)}{(-16.1}-23.9\end{array}$ & $\frac{-19.1}{(-16.6,-25.2,-23.1)}$ \\
\hline & $22 \mathrm{Jan}$ & $\begin{array}{l}-22.5,-25.8 \\
(-16.5,-22.6)\end{array}$ & $\begin{array}{l}-22.6,-25.6,-26.0 \\
(-16.4,-22.7)\end{array}$ & $\begin{array}{l}-22.8,-26.8,-27.8 \\
-27.9(-16.4,-23.1)\end{array}$ \\
\hline 19 Mar. 1990 & 22 Mar. & $\begin{aligned}-10.0,-16.3 \\
(-16.3,-22.7)\end{aligned}$ & $\begin{array}{l}-13.4,-34.2,-35.1 \\
\quad(-16.2,-22.4)\end{array}$ & $\begin{array}{c}-18.1,-19.6,-19.8 \\
(-16.2,-22.7)\end{array}$ \\
\hline & 26 Mar. & $\begin{aligned}-18.1,-28.1 \\
(-16.4,-22.3)\end{aligned}$ & $\begin{array}{l}-23.6,-24.1,-26.5 \\
-32.3(-16.4,-22.6)\end{array}$ & $\begin{array}{c}-28.4,-29.4,-29.9 \\
-31.0,-31.4 \\
(-16.4,-22.5)\end{array}$ \\
\hline
\end{tabular}

${ }^{2}$ Values in parentheses indicate the calculated temperature at one-half the area of the broad exotherms.

yUnderlined exotherm temperatures indicate that the abrupt LTE peak height was $\leq 3 \mathrm{~mm}$.

Table 3. DTA of 'Red Lake' and 'Danka' currant canes.

\begin{tabular}{|c|c|c|c|c|}
\hline \multirow{2}{*}{$\begin{array}{c}\text { Collection } \\
\text { date }\end{array}$} & \multirow{2}{*}{$\begin{array}{c}\text { DTA } \\
\text { test date } \\
\end{array}$} & \multicolumn{3}{|c|}{$\operatorname{TPA}_{50}\left({ }^{\circ} \mathrm{C}\right)^{\mathrm{z}}$} \\
\hline & & Cane 1 & Cane 2 & Cane 3 \\
\hline $\begin{array}{l}17 \text { Jan. } 1990 \\
19 \text { Mar. } 1990\end{array}$ & $\begin{array}{l}24 \text { Jan. } \\
27 \text { Mar. } \\
28 \text { Mar. } \\
28 \text { Mar. }\end{array}$ & $\begin{array}{ll} & \text { Red Lak } \\
-21.5, & -44.1 \\
-20.6, & -33.7 \\
-21.9 & \\
-20.9 & \end{array}$ & $\begin{array}{l}-21.0,-43.1 \\
-20.6,-34.2 \\
-21.7,-34.9 \\
-20.7\end{array}$ & $\begin{array}{l}-21.3,-42.3 \\
-20.5,-34.2 \\
-21.5,-34.6 \\
-20.8\end{array}$ \\
\hline $\begin{array}{l}17 \text { Jan. } 1990 \\
19 \text { Mar. } 1990\end{array}$ & $\begin{array}{l}24 \text { Jan. } \\
1 \text { Feb. } \\
27 \text { Mar. } \\
29 \text { Mar. }\end{array}$ & $\begin{array}{ll} & \text { Danka } \\
-22.3 & \\
-16.9, & -22.9 \\
-17.8, & -24.7 \\
-23.7 & \\
\end{array}$ & $\begin{array}{l}-17.3,-24.2 \\
-17.5,-23.5 \\
-18.1,-24.1 \\
-23.9\end{array}$ & $\begin{array}{l}-23.4 \\
-17.7,-23.7 \\
-18.0,-24.1 \\
-17.4,-24.3 \\
\end{array}$ \\
\hline
\end{tabular}

${ }^{z}$ The calculated temperature at one-half the area of the exotherm. 


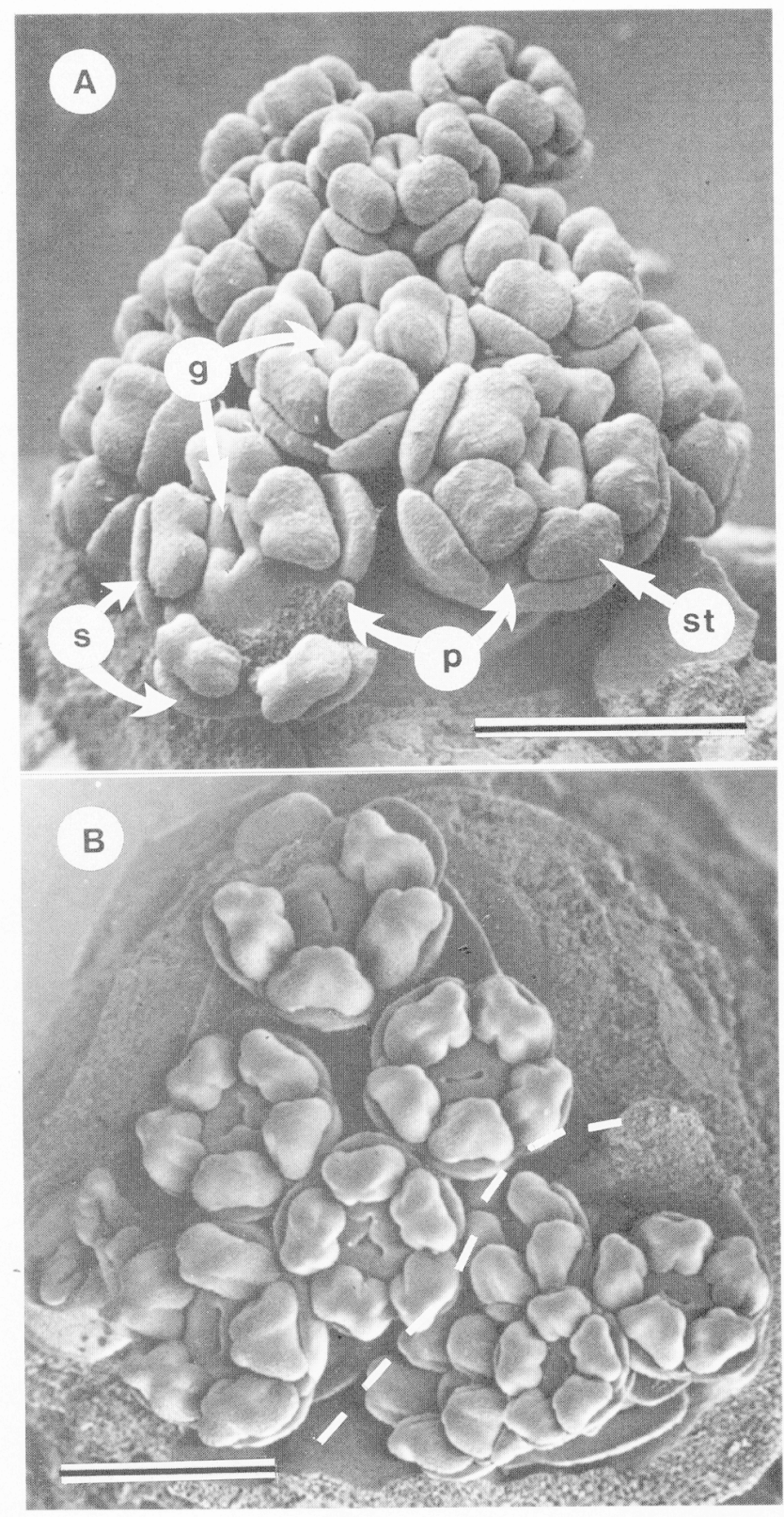

Fig. 3. SEM of dissected axillary buds of red and black currants. (A) Longitudinal view of 'Red Lake' red currant inflorescence sampled on 19-Mar. 1990. Note the numerous floral primordia on a single axis with differentiated sepals (s), petals (p), stamen (st), and gynoecia (g). (B) Axillary bud of 'Danka' black currant viewed from the top. Dotted lines delineate two racemes. Bar $=0.5 \mathrm{~mm}$.

of -14 to $-20 \mathrm{C}$ and -20 to $-25 \mathrm{C}$ (Fig. 2). The average $\mathrm{TPA}_{50}$ of the first exotherm was -16.4 , - 16.7, and $-16.3 \mathrm{C}$ in November, January, and March, respectively. The average $\mathrm{TPA}_{50}$ of the second exotherm was $-23.2 \mathrm{C}$ at the first two sampling dates and $-22.5 \mathrm{C}$ at the final date. The $\mathrm{TPA}_{50}$ has been used previously to quantify similar exotherms (George et al., 1977). Bud scales and leaves surrounding the inflorescence of 'Red Lake' samples were removed in the 19 Nov. test to determine whether the broad exotherm was associated with freezing outside the floral axis. DTA results were similar to those detected from intact buds. Experiments conducted on 'Danka' samples in Dec. 1990 revealed that the broad exotherm in the range of -14 to $-20 \mathrm{C}$ was present when the floral bud (Fig. 3) was removed from the cane sample and when phloem and periderm tissues or nonliving periderm was subjected to DTA, regardless of the cooling rate. In contrast, the broad exotherrn at -14 to $-20 \mathrm{C}$ was not observed when the pith and xylem tissues were tested. George (1982) reported a similar exotherm that was associated with supercooling of water in the nonliving periderm of Juniperus virginiana L. stems. This exotherm was unrelated to injury in the stem tissue. The second broad exotherm, detected from 'Danka' bud samples in the range of -20 to $-25 \mathrm{C}$ in DTA experiments conducted in Nov. 1989 through Mar. 1990, was not apparent in experiments conducted in Dec. 1990. Thus, it is unclear if this second broad exotherm is related to freezing injury in 'Danka' floral buds.

Viability tests. None of the buds examined exhibited oxidative browning, after exposure to temperatures at or below $-36 \mathrm{C}$. However, at all three sampling dates, the floral tissue appeared turgid at $-24 \mathrm{C}$, but was flaccid and water-soaked by $-27 \mathrm{C}$. The similar hardiness response at all test dates maybe attributed. to exposure to temperatures below $-5 \mathrm{C}$ in the, 7 days preceding each collection.

Examination of the buds after freezing revealed that the inflorescence of all samples was well developed by November. In 'Red Lake' buds, as many as 25 flowers were noted under the dissecting microscope, while up to 15 flowers were present in 'Danka' buds. In red currant, flowers are generally borne along a single raceme per bud, while those of black currant occur on one to four short racemes (Harmat et al., 1989; Wright, 1985). Flowers in both species had differentiated sepals, petals, stamen, and carpels by 13 Nov. (Fig. 3). The number of LTEs detected from DTA samples did not correspond to the number of flowers on racemes in each bud. The large peak size of most of the abrupt LTEs may indicate that several flowers froze simultaneously. Since the flowers did not exhibit oxidative browning in the viability test, it was impossible to verify the number of flowers injured at specific test temperatures. Attempts to quantify floral injury using 2,3,5-triphenyltetrazolium chloride were also unsuccessful. Moreover, it is uncertain if the very small LTEs $(\leq 0.3 \mathrm{~mm}$ differential temperature) are related to freezing in individual flowers. Although the DTA results are difficult to interpret, water-soaked floral tissue was observed near the median LTE value.

In conclusion, supercooled tissue water was detected in floral buds of 'Red Lake' red currant and 'Danka' black currant. DTA experiments revealed multiple abrupt LTEs and one or two broad LTEs in bud samples. Abrupt LTEs appeared to be related to inflorescence injury. The broad LTE detected in the range of - 14 to $-20 \mathrm{C}$ in 'Danka' samples was associated with freezing in the nonliving periderm of the cane.

\section{Literature Cited}

Andrews, P.K. and E.L. Proebsting. 1983. Differential thermal analysis freezing injury of reacclimating peach and sweet cherry reproductive organs. J. Amer. Soc. Hort. Sci. 108:755-759.

Burke, M.J., L.V. Gusta, H.A. Quamme, C.J. Weiser, and P.H. Li. 1976. Freezing and injury in plants, p. 507-528. In: W.R. Briggs, P.B. Green, and R.L. Jones (eds.). Annual review of plant physiology. Annual Reviews, Palo Alto, Calif.

Dale, A. 1981. The tolerance of black currant flowers to induced frosts. Ann. Applied Biol. 99:99-106.

Dale, A. and N. Heiberg. 1984. Studies in black currant on the relationship between frost tolerance in winter and spring and on the relationships of rehardening and rehardening in spring. Crop Res. 24:73-83. George, M.F. 1982. Freezing avoidance by supercooling of tissue water in vegetative and reproductive structures of Juniperus virginiana, $\mathrm{p}$. 
367-377. In: P.H. Li and A. Sakai (eds.). Plant cold hardiness and freezing stress. vol. 2. Academic, New York.

George, M. F., M.J. Burke, and C.J. Weiser. 1974. Supercooling in overwintering azalea flower buds. Plant Physiol. 54:29-35.

George, M. F., S.G. Hong, and M.J. Burke. 1977. Cold hardiness and deep supercooling of hardwoods: Its occurrence in provenance collections of red oak, yellow birch, black walnut, and black cherry. Ecology 58:674-680.

Harmat, L., A. Porpaczy, D.G. Himelrick, and G.J. Galletta. 1989. Currant and gooseberry management, p. 245-272. In: G.J. Galletta and D.G. Himelrick (eds.). Small fruit crop management. Prentice Hall, Englewood Cliffs, N.J.

Keep, E., W..H. Grafton, V.H. Knight, and I.G. Cumming. 1983. The response of black currant cultivars and selections to spring frost. J. Hort. Sci. 58:535-540.

Kraut, J. L., C.S. Walsh, and E.N. Ashworth. 1986. Acclimation and winterhardiness patterns in eastern thornless blackberry. J. Amer. Soc. Hort. Sci. 111:347-352.
Lobanov, E.M. and A.S. Shcherbinin. 1990. Effect of photoperiod and temperature on the initial stages of frost resistance formation in black currant. Soviet Plant Physiol. 37:439-446.

Mather, P. J. C., I. Modlibowska, and E. Keep. 1980. Spring frost resistance in black currants. Euphytica 29:793-800.

Pope, M.I. and M.D. Judd. 1977. Differential thermal analysis. Heyden \& Son, London.

Quamme, H-A. 1974. An exothermic process involved in the freezing injury to flower buds of several Prunus species. J. Amer. Soc. Hort. Sci. 99:315-318.

Warmund, M.R. and M.F. George. 1990. Freezing survival and supercooling in primary and secondary buds of Rubus spp. Can. J. Plant Sci. 70:893-904.

Warmund, M. R., M.F. George, and B.G. Cumbie. 1988. Supercooling in 'Darrow' blackberry buds. J. Amer. Soc. Hort. Sci. 113:418422 .

Wright, C.J. 1985. Ribes, p. 198-203. In: A.H. Halevy (ed.). CRC handbook of flowering. vol. 4. CRC Press, Boca Raton, Fla. 